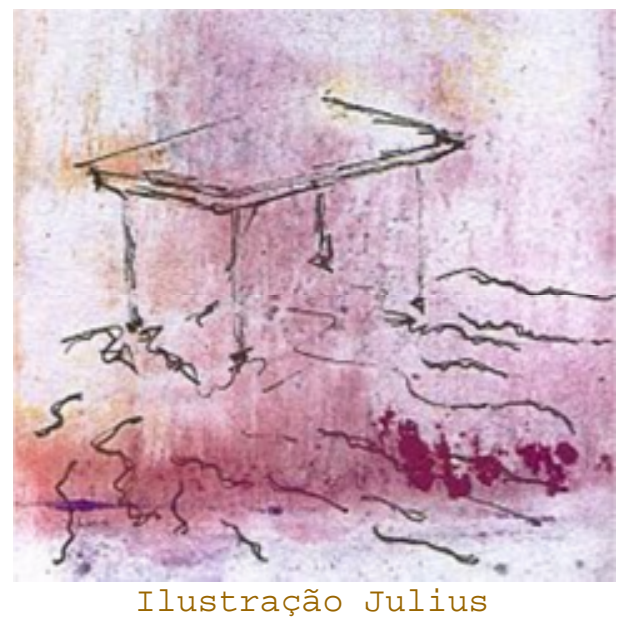

\title{
Apenas é
}

para Júlio

\section{Lenise Regina}

Lenise Regina é estudante de letras da UFMG e desenha círculos no papel enquanto escreve. integrante do grupo POESIAhoje, dá passos em torno de labirintos sem centro. tem trabalhos publicados nas revistas ETECETERA e Mininas. por vezes apaga formas com os dedos. mantém o blog palavrasemnom e onde publica sobre música, web e alguma poesia, e na sombra de suas memórias desenha letras como pontos de fuga.

Ainda na soleira da porta vi a dimensão das costas que encobriam a mesa. Olhos atentos e dedos já saudosos pelo toque, embora ainda refugiados nos bolsos de minha calça. Um breve instante mais e meus pés se recusariam a levar-me a qualquer lugar que eu desejasse. Permaneci ali na iminência de um acontecimento maior ou igual à vontade de meus membros inferiores. Dois segundos mais e uma escassez de ar em meu cérebro.

Aproveitei a decisão precipitada do vento, em empurrar a porta, e entrei antes que ele a batesse.

Nem o peso do carvalho, açoitando as dobradiças poderia tirálo do transe em que estava imerso. Usava as mãos, os dedos, e enfim todo o corpo; rascunhava o papel com ânsia. Perscrutavalhe cada espaço em busca do preenchimento total de sua incômoda alvura. 
Caminhei pelo cômodo indiferente a seu olhar. Passei por entre paredes, fiz sombra sob as cortinas e finalmente presença sob - corpo teso e inerte acomodado na cadeira.

Sem levantar os olhos do papel, perguntou o porque de meu prematuro retorno. Porque a pouca luz? E as cores fortes dos quadros nas paredes? Ele permaneceu com os olhos descolados do rosto, imersos no escuro do silêncio. Espatifei novamente o silêncio em pequenos cacos. Gosto dessas cores fortes e da sensação de medo que elas me provocam. Pareceu não me ouvir, tamanho seu embate com a letra. A cada nova tentativa de preenchimento, o papel a sua frente retornava a seu insosso estado de alvura. Com a cabeça entre as mãos, a figura mal delimitada, um tanto cadeira, um tanto mesa, parecia querer entrar para dentro de em si. Parecia disposto a engolir tudo o que lhe coubesse. Então abandonou bruscamente a folha de papel...

Toquei-a e pude sentir, aproximei meus ouvidos e sussurrei... As palavras sempre estiveram aqui, por isso voltei. Pude ver em seus olhos o reverbero da resposta ainda cheirando a mofo.

Olhou a mancha já engolindo a branquidez do papel e aos poucos presenciou a revelação da escrita do que não se pode escrever, porque não se sabe como. Ergueu o olhar, levantou-se da cadeira em direção à porta, fechou-a por dentro. Voltou os olhos em minha direção. Agora, não haverá mais ventos que ampliem distâncias e apaguem os rastros de casa; nem mais papéis ao chão. Ofereceu-me uma cadeira, sentei-me a seu lado. 